\title{
A Study of the Teaching of ESL Writing in Colleges in China
}

\author{
Haiwen Mo \\ Associate Professor, Applied Linguistics \\ School of Foreign Languages, Guangxi Teachers Education University \\ Minxiudong Road 175, Nanning 530001, Guangxi, China \\ E-mail: vitormhw@163.com
}

Received: February 21, 2011

Accepted: June 26, $2011 \quad$ Published: February 1, 2012

doi:10.5539/ijel.v2n1p118

URL: http://dx.doi.org/10.5539/ijel.v2n1p118

\begin{abstract}
In China, ESL teaching constitutes an important part of higher education and ESL writing is a required skill for non-English majors in colleges and universities. However, the teaching of college English writing is unsatisfactory and problematic. The author did a survey on the teaching of ESL writing in five universities in China by using the methods of questionnaire, interview and sample collection. The results of the survey indicate that the students' deficiency in English writing is due to personal and instructional reasons, such as ineffective teaching, students' lack of interest in writing, students' poor linguistic competence, students' lack of the cultural knowledge of the target language and so on. In the teaching of college English Writing, the teacher should boost students' motivation, integrate reading with writing, and provide effective feedback to the students.
\end{abstract}

Keywords: College English, Teaching of ESL writing, Approach, China

\section{Introduction}

According to the College English Curriculum Requirements (for Trial Implementation) by China Education Ministry in 2004, the objective of College English teaching in China is to develop students' ability to use English in an all-round way, so that in their work and social interactions they will be able to exchange information effectively through both spoken and written ways in future, and at the same time they will be able to enhance their ability to study independently and improve their cultural quality so as to meet the needs of China's social development and international exchanges. English writing is an essential and integral part of English learning and an important skill for the undergraduate of non-English majors. However, English writing is difficult for most of Chinese college students. Many teachers and experts (Pan, 1998; Liu, 1999; Cai, 2002; Yang, 2006) consider that College English writing in China is unsatisfactory and problematic, and they reveal that the writing competence of college students can't meet the requirements of the college English syllabus and the needs of the society. To improve college students' writing proficiency, the study of college English writing is urgently needed. The author, on the basis of second language writing theories, has conducted a study of college English writing teaching in five universities in China, tries to find out the reasons that hinder the development of students' writing competence, and puts forward some suggestions for the teaching of college English writing in China.

\section{Literature Review}

For many years, the teaching of writing was neglected as a result of concentration on the aural approach (Brookes \& Grundy, 2000). It is true that there was a specific demand for spoken language, but the importance of writing should be equally valued. "How to teach writing" in ESL classes is a question that has no definite answer. Different teachers have different teaching styles and methods.

Experts and teachers have stressed many features of ESL writing, and they have developed a variety of approaches to the teaching of writing. Raimes (1983) presents six approaches to the teaching of writing: the controlled-to-free approach; the free-writing approach; the paragraph-pattern approach; the grammar-syntax-organization approach; the communicative approach; the process approach. Nunan (2003) firstly gives a brief comparison between process and product approaches to the teaching of writing, and then presents the functional grammar approach and the discourse-based approach for writing. He also gives some suggestions on teaching: a writing program should incorporate elements of process and product approaches; a teacher should create his own professional practice in the teaching of second language writing based on the 
related theories.

Many researchers and teachers have studied ESL Writing in Colleges in China from different perspectives. Liu (1999) suggests that college English teachers should attach great importance to writing teaching, and calls for the reform of syllabus design and the establishment of college English writing courses for non-English majors. Cai (2002) and Huang (2004) give a detailed analysis of the teaching of college English writing from a testing perspective. From the psychological perspective, Zhang (2009) investigates the students' psychological obstacles in English writing and then gives some suggested solutions. Guo and $\mathrm{Ou}$ (2010) carry out an empirical research for college students' writing training, exploring students' sensing capability for mistakes and formation of writing thought, and then demonstrate the efficiency of the teaching approaches under the direction of Error Analysis Theory for improving college students' writing abilities. The above studies have enlightened to college English teaching and reform and now the universities and colleges in China are carrying out the college English teaching task on the basis of College English Curriculum Requirements (For Trial implementation).

\section{The Survey on the Teaching of College English Writing in China}

\subsection{Subjects}

The subjects of the study involve 50 college English teachers and 200 non-English majors from five universities in China: Guangxi University, Guangxi Teachers Education University, Guangxi Normal University, Guangxi University of Technology and Yulin Normal University. 10 teachers and 40 students are chosen from each of the above universities.

\subsection{Instruments}

(1) Two written questionnaires. The two questionnaires are respectively designed for the college English teachers and college students with reference to the questionnaire designed by Liu Runqing and Dai Manshu (2004), and aim to investigate the current situation of college English writing teaching. In the questionnaires, all the questions are written in Chinese. The questionnaire for the teachers has three parts involving eleven questions. (2) Follow-up interview. Five experienced college English teachers, and ten college students from the Department of Chinese Language and Literature of Guangxi Normal University were interviewed to probe the teaching of college English writing. Finally, all the questionnaires for the teachers and 174 questionnaires for the students were collected, with 49 of the questionnaires for teachers and 151 questionnaires for students being valid.

\subsection{Results}

\subsubsection{College English teachers' age, degree, and professional post}

\section{$<$ Insert Table 1 here $>$}

Table 1 shows that $69.4 \%$ of the college English teachers are 35 years old or less than 35 years old; $77.6 \%$ of them have bachelor's degree, and only $22.4 \%$ of the college teachers have a master's degree. Table 1 also suggests that only $14.2 \%$ of college teachers have a high professional post. Most of the young college teachers are enterprising and have a good command of English, which is very helpful in improving the quality of teaching. However, the disadvantages are also obvious. Many college teachers just graduated from the universities, and they lack teaching experience, and feel at a loss to find a good resolution to improve the students' writing ability.

\subsubsection{A brief description of the teachers' instruction of college English writing}

$<$ Insert Table 2 here $>$

Table 2 indicates $75.5 \%$ of the investigated teachers have carefully prepared for the lessons and attach great importance to the writing parts of the textbook. Unfortunately, $20.4 \%$ of the teachers do not make full use of the writing exercises for some reasons. Even worse, $4.1 \%$ of the teachers are not familiar with the textbook, and as a result, they could not help the students improve their writing ability successfully. The investigation also implies that most of the college teachers have more than 14 periods every week. Most of the teachers complain that they are burdened heavily with the teaching task and have little time to consider the appropriate resolutions to improve the students' writing skills. In one semester, most of the teachers (about 73.5\%) just assign 3-6 topics (or less) to the students as the writing exercise, and then after correcting some grammatical errors, they return the papers to the students without giving any suggestions on writing skills.

3.3.3 The teachers' opinions on the students' writing

$<$ Insert Table 3 here $>$

Table 3 shows the results as follows: Most of the students lack interests in ESL writing, and 59.9\% of them do not like or even hate ESL writing and $40.1 \%$ of them are not very highly motivated; writing is a skill with many 
difficulties for the students to overcome, and the lack of vocabulary is the most difficult for them; the sequence of difficulties is: Vocabulary $>$ Writing skills and techniques $>$ Grammar $>$ Cultural differences between Chinese and English; CET4 has negative influence on the teaching of English writing.

\subsubsection{The Students' views on the teaching of college English writing}

$<$ Insert Table 4 here $>$

Table 4 shows that the teaching of college English writing is far from the students' satisfaction $(75.5 \%$ of the students are unsatisfied with the current situation of the college English writing teaching); the students do not show a positive attitude toward CET4 as for the improvement of writing competence; most of the universities do not attach great importance to the teaching of college English writing.

\subsubsection{The students' attitudes toward English writing}

$<$ Insert Table 5 here $>$

Table 5 indicates that the students are not intrinsically motivated; $66.3 \%$ of them want to improve writing competence in English with a purpose of passing the examination or getting a good job. The students are reluctant to write in English, such as English emails, English letters, etc. After class, $45.1 \%$ of the students have never written any articles in English except the assigned exercises; $31.1 \%$ of them just write one or two English essays. For the students, the most needed English skills are listed as follows: oral English $>$ reading $>$ listening> writing. Although the students are poor in writing, it is the least wanted skill for them to improve.

\subsubsection{The students' difficulties in English writing}

$<$ Insert Table 6 here $>$

Table 6 shows that for $55.6 \%$ students, vocabulary is the most difficult factor that hinders English writing; Lack of interest is the most serious problem in the teaching of college English writing; the teaching of college English writing is far from satisfactory, and most of the students $(84.1 \%$ of them) agree and $12.6 \%$ of them partly agree that the teaching of college English writing should be strengthened.

\subsection{Analysis and discussion}

\subsubsection{The analysis of teachers' difficulties in teaching}

The teaching of writing in English is an integrated task for college English teachers in China, but it has been neglected for many years for various reasons. Many people think that in English teaching, the most important things are reading, listening and speaking, but not writing which is good to have but not indispensable, since most of the students will not have to write in English a lot in their future work. This ignorance could obviously be seen from the collected data and the interview. Among 49 investigated college English teachers, 19 of them just spend 3 or less than 3 periods in teaching writing in one semester. Some even have never given in-class writing instruction, and they just assign writing topics and assess the students' writing with the grade A, B, C or $\mathrm{D}$ after correcting some grammatical errors. The data collected show that $55.1 \%$ of the investigated teachers have to teach 14 or more periods in a week. No wonder many college English teachers in China complain that they are heavily burdened with teaching tasks, and have little time to consider the right teaching techniques to improve students' writing competence in and out of class. Every week, the teachers just have 4 or 5 English periods for one class. Insufficient class hours prevent the teachers from fulfilling the teaching program. Because of the limited time, many teachers often teach English writing in several minutes at the end of each unit. Getting little stimulation, the students do not feel interested in English writing, which results in their reluctance to write in English. Among the teachers investigated, $32.7 \%$ of them are 25 or less than 25 years old; $77.6 \%$ of them just have B.A degree; $85.8 \%$ of them are assistant teachers or lecturers. Most of them do not have any background in teaching English writing, nor do they have any training in it. Actually, some teachers really want to do something more to help the students in writing, but they lack experience in teaching writing and feel puzzled about right techniques and the proper ways to help the students. They use their own teaching methods based on their learning experience and the CET4 writing grading criteria focusing on grammar. Some interviewed teachers believe that a good English essay should have as few grammatical errors as possible. It is apparent that their methods of teaching English writing mainly focus on the grammatical correction of the students' final products, without giving efficient guidance to the students in the process of writing.

\subsubsection{The analysis of the college students' problems}

English is a second language for college students in China, so it is not surprising that English writing is unpopular with most of the investigated college students, who are still developing their English language skills. The problems that the college students may encounter in English writing are various as follows. 


\section{(1) Lack of interest}

It seems only sensible to assume that learning is most likely to occur when we want to learn (Williams \& Burden, 2003 , p.111). The result of the questionnaire shows that $53.7 \%$ of the students are not interested in English writing. In the interview, many students also expressed their dislike of English writing. Some students said that they did not hate English writing, yet English writing was so difficult that they had to spend several hours drafting and revising their writing, but each time, they felt discouraged with the errors marked with red pen by the teacher and the poor grade. Boring instruction also constitutes one of the reasons that the students feel no interest in writing. Many university students showed their dissatisfaction with the teaching of writing in the interview. They complained that the teacher did not attach importance to the teaching of writing, and the teacher often teaches English writing within ten minutes in one unit; sometimes the teacher even skips over the writing part and gives no instructions on writing. Without proper guidance, the students are not clear about the demands of their writing assignment, and usually feel at a loss to write in English, which makes the students become more uninterested in English writing. 41.1\% of the investigated students believe that lack of interest is the most serious problem in the teaching of college English writing.

(2) Linguistic problems

In the interview, the college English teachers all agreed that most of the college students were poor in English writing and some of them made so many errors in writing that the teachers could not tell what they wanted to say. For the purpose of exploratory study of the linguistic problems, the author has collected and analyzed some compositions written by some students in Grade 2004 of Guangxi Normal University.

\section{Sample 1 Why Do People Move to Big Cities?}

(1)Nowdays(Nowadays), there are more and more people who live in big cities. It is reported that a lot of (2)villageres (villagers) move to(3) the big city. for example Shenzhe. Guangzhou. Guangdong(the big cities, such as Shenzhen, Guangzhou and so on.).

Why have there been so many people moving to city? Maybe the reasons can be listed as follows. The first one is that many students (4) are graduate (graduate) from school every year. There is high salary in big city. So the graduates crowd into city. The second reason is that (5) workeres(workers)go to find(6) job(jobs). (7) it is (There are)more chances in big cities than in small towns.

So (8)the people (the number of the people) is increasing gradually in big city [cities]. The phenomenon is good for the economy. (9) But (However,) the city environment is more polluted than before.

Sample 2 How to Deal with the Relationship with Others on Campus

In the university, all of us feel very busy. Our footsteps are so fast that we can't spare much time to think about ourselves. Now I want to ask a question: have you ever thought how to deal with the relationship with others on the campus?

(10) That (It) is an important part in our university life to deal with the relationship with others. First, we should (11) be accustomed to touch the strangers (learn to communicate with strangers). Before entering university, the persons we (12) touch (contact) every day are mostly acquaintances, but (13) in the campus (on campus), (14) most of time we need to touch the strangers (we need to spend much time contacting others). So we must make ourselves be accustomed to (15) communicate (communicating) with strangers. That is the basis of entering (16) the society (society). Second, we must (17) contact well with (communicate well) our roommates. For most of us, it is the first time for us to live in dormitories. So how to communicate with (18) the others (others) may be a big problem. Sometimes, we may have (19) conflict (squabbles) with each other. It is hard to avoid, but we should be magnanimous. We should try to make friends with each other and help each other. With the friendship, (20) our university life will be more wonderful (we will have a more wonderful university life)!

Life is transitory. The four-year university life is the most beautiful part of it. If you can have a good relationship with others, you will surely lead a happy life in the university.

Sample 1 and Sample 2 have many linguistic errors, which were classified and listed as follows:
a. Laps/pen slips: (1), (2), (5)
b. Misinformation/word choice error: (3), (8), (9), (10), (19)
c. Voice error: (4)
d. Number error: (6)
e. Syntactical error: (7), (20) 
f. L1 transfer error: (11), (12), (14)

g. Collocation error: (13), (15), (17)

d. Article error: (16), (18)

The students could not use the right words or phrases to express appropriately what they intended to say. From these essays, we see that there are many linguistic errors, which have been underlined and corrected in the blankets. The linguistic errors include lexical, syntactical, logical ones, and some sentences, influenced by L1 transfer, seem confusing and difficult to revise.

After correcting the compositions, the author interviewed the students who wrote these compositions. They admitted that they were not interested in English writing and had done little reading and writing practice in their spare time; it was very difficult for them to find the right words or phrases to express themselves at a precise level of accuracy in English writing. After finishing writing, they did not have the desire to revise it and hurried to hand in the composition to the teacher. No wonder there are so many errors in their essays. The investigation also indicates that even some easy words may be used incorrectly without much practice in English; the students feel confused, bored or even distressed with English writing.

(3) Cultural cognitive problems

Language and writing are cultural phenomena, and a different language has its unique rhetorical conventions. As a result, L1 linguistic and rhetorical conventions interfere with L2 writing. Students from different backgrounds develop their ideas in different ways. Compared with the essentially linear pattern of English paragraphs, Arabic speakers produced texts based on a series of parallel coordinate clauses; "Oriental" writers, such as the Chinese writers, used an indirect approach and come to the point only at the end; and French, Spanish, and Russian writers digress and introduce extraneous material far more often than English writers (Connor, 1996, p.16).

Languages and thoughts are intimately related in the way that language is the means of thought. Owing to the difference between English and Chinese thinking patterns, the Chinese students present their ideas quite differently from the English people. Connor (1996) argues that Chinese as well as other "oriental" writing was indirect; a subject was not discussed directly but was approached from a variety of indirectly related views; the Chinese writers tended to suggest or be indirect and use rhetorical questions, analogies, and anecdotes to reveal intentions.

Liu (2002) maintains that Chinese students rely heavily on L1 strategies in L2 writing, and the way of Chinese thinking sometimes has strong negative transfer on English writing. We can see that in the investigation, $12.2 \%$ of teachers consider the differences between Chinese and English cultures as the biggest problem for the students' English writing; $16.6 \%$ of the students view the cultural differences as the most difficult aspect for English writing; $74.3 \%$ of the students usually or sometimes firstly organize the text in Chinese and then translate it into English.

\section{Suggestions}

All approaches have their advantages, and the teacher should not be so keen on one approach and excluded all others. The approaches can complement each other in the stages of the teaching of English writing. Therefore, the author suggests teaching ESL writing in a comprehensive way.

\subsection{Boosting students' motivation in English writing}

Goals act as central components in cognitive approaches to motivation. In making the decisions to engage in an activity, setting appropriate goals becomes an important part of motivated behaviors so that the decision can be carried out and the required effort sustained (Williams \& Burden, 2003, p.130). As for English writing, teachers should make the students understand the College English Curriculum Requirements and help the students to set up the appropriate goals according their English level. In Grade one, the college students just graduated from senior high school and have great enthusiasm in English learning. However, they do not have a good command of English and English writing seems difficult for them. The teachers should encourage the students to try to reach the basic requirements of writing in Grade One and then encourage them to study hard and try to reach the intermediate and higher requirements in writing step by step.

To boost students' motivation in English writing, the writing activities must be authentic, enjoyable and practical. Students will be more actively involved in English writing when it becomes meaningful and authentic to them. Writing is a form of communication and one can only write effectively when one has something meaningful to say. Therefore, writing activities, such as describing shopping and traveling, writing letters, greetings cards or emails and so on are good tasks to relate writing with students' real life. Experimenting with these practical 
writing tasks, the students will be practicing writing in English and learning about the conventions of English culture. "Write a composition telling why you would like a new bicycle is not as meaningful as you have entered a competition to win a new bicycle. The winner will be the one who writes the most convincing reasons why he or she wants that bicycle. Try to win the competition". (Raimes, 1983, p.120)

\subsection{Integrating reading with writing}

Reading provides means for acquiring linguistic knowledge and writing reinforces the acquired linguistic knowledge by its application in written work. Reading and writing are seen as a complementary process. Reading extensively makes the students aware of the way in which English is used as a written communication, and reading can help the students develop the techniques of reading and get a guide for writing. The ways to integrate reading with writing are various. Here the author just lists two ways to illustrate the possibility and importance of the integration of reading and writing.

Summarizing provides students with valuable practice in searching for information and summarizing the meaning. When students are reading extensively to gain more information and knowledge, they can write a summary based on the articles or books they have read. When facing a reading passage, they have to find out what the main ideas are and try to express them in their own words. The ability to understand concepts, process and restate the articles or books in one's own words is essential for language learning. Summarizing makes the students distill and rewrite the content in a brief way, and it is an effective way to improve the students reading and writing competences.

Imitation is also an important factor in learning how to write. Generally speaking, the texts chosen for the intensive reading for the college students are mostly concerned with cultures, morality, and social phenomena of the western countries. All these different themes of articles can serve as the models for the college students to imitate. In the class, the teachers can firstly analyze different styles of writing to the students, and explain the ways of wording, detailed descriptions, and rhetorical devises of the articles. After learning the text, the teacher can ask the students to write an article by imitating. Facts have proved that imitation is not only an effective way to deepen the students' understanding of the texts, but also a good way for them to acquire the skills of English writing.

\subsection{Providing effective feedback to the students}

Feedback can help the students assess how effective his/her work is and it makes a central and critical contribution to the evolution of a piece of writing. Positive or formative feedback provides opportunities for students to see how others respond to their work and gives help to the students in repairs and amendments. However, the previous investigation has indicated that inappropriate feedback is a main factor that de-motivates the college students in English writing, and it is to some extent responsible for the students' poor performance in English writing. Here are some basic principles for giving feedbacks: when you pick up a student's piece of writing, don not immediately reach for a pen or pencil and read the whole piece through first before you write anything; look for strengths as well as weaknesses, and let the student know what the strengths are; if you use any editing symbols, make sure that the students are familiar with all of them and know what to do when they see one; work out your own strategy for handling errors and explain it to the student.

Teachers' feedback plays a central role in the teaching. The most common type of written feedback is the hand-written commentary on the student's paper. This kind of feedback is best seen as responding to the student's writing, stating how the text appears to the teacher as the reader, how successful the teacher think it has been, and how it could be improved. Written comments can take the form of a paraphrase of the ideas expressed, such as praise, questions, or suggestions, etc. From the interview, we know that the college teachers in China usually just focus on the grammatical or spelling errors of in students' articles, and then give the students a final comment like "Good", "Fairly done", or "Needs more work". These comments seem inefficient for the students' improvement. The students would get confused what to do next. Therefore, the teacher should give more specific comments and attach more importance to the content, rhetoric, and organization of the students' writing. Hyland (2003, p.187) gave us some suggestions on written comment:

(1) Write personalized comments - maintaining a dialogue between reader and writer.

(2) Provide guidance where necessary - avoiding advice that is too directive or prescriptive.

(3) Make text-specific comments - relating comments to the text rather than general rules.

(4) Balance positive and negative comments - avoiding discouraging students with criticism.

Praise should be used to encourage students, particularly in responding to ideas in a text. We believe that 
noticing and praising whatever a student does well improved writing more than any kind of amount of correction of what he does badly. Teachers therefore need to apply positive feedback to students' work, for a lack of positive comments can affect both students' attitudes to writing and their reception of feedback.

\section{Concluding remarks}

The author has probed the current situation of college English writing teaching in China through investigation and finds that the college students' writing ability is far from satisfactory. This case results from various reasons, such as ineffective teaching, students' lack of interest, students' poor linguistic competence, students' lack of cultural knowledge of the target language and so on. The results of the investigation indicate that the teaching and learning of English writing exists many problems. In order to improve China's college students' writing ability, the college English teachers should change their role from a controller to a facilitator, by organizing effective writing instruction, and stimulating the students' motivation and autonomy in English writing. In short, the teaching of college English writing should be student-centered and has a good combination of the teaching tasks with the development of skills, attaches great importance to the development of the students' comprehensive language ability, so as to better improve the teaching quality of college English in China.

\section{References}

Brookes, A. \& Grundy, P. (2000). Beginning to Write. Cambridge: Cambridge University Press.

Cai, Jigang. (2002). Influence of CET Writing Requirements and Criteria on Chinese Students' Composition. Journal of PLA Universities of Foreign Studies, (5), 49-53.

Connor, U. (1996). Contrastive Rhetoric, Cross-cultural aspects of second-language writing. Cambridge: Cambridge University Press.

Guo, Xiaohua \& Ou, Yangjing. (2010). A New Exploration of College English Writing Based on Error Analysis Theory. Foreign Language and Literature, (2), 137-140.

Huang, Jianbin. (2004). College English Teaching Requirement and CET Test Reform. China University Teaching, (11):35-36.

Hyland, K. (2003). Second Language Writing. Cambridge University Press. http://dx.doi.org/10.1017/CBO9780511667251

Liu, Donghong. (2002). Freshmen's writing L1 Strategies and L1 Transfer. Foreign Language Education, (4), 35-39.

Liu, Hailing. (1999). A Study of College English Writing. Foreign Languages and Their Teaching, (8), 21-23.

Liu, Runqing \& Dai, Manchun. (2004). China College Foreign Language Teaching Reform. Beijing: Foreign Language Teaching and Research Press.

Ministry of Education of China. (2004). College English Curriculum Requirements (for Trial Implementation). Shanghai: Shanghai Foreign Language Education Press.

Nunan, D. (2003). Second Language Teaching and Learning. Beijing: Foreign Language Teaching and Research Press.

Pan, Jun. (1998). A Survey of the Teaching of College English Writing. Foreign Languages and Their Teaching, (8), 24-27.

Raimes, A. (1983). Techniques in Teaching Writing. Oxford: Oxford University Press.

Williams, M. \& Burden, R. L. (2003). Psychology for language Teachers. Beijing: Foreign Language Teaching and Research Press.

Yang, Huizhong. The Speech on the Third CET Conference. [Online] Available: http://www.tefl.org.cn (January 15, 2006).

Zhang, Lichang. (2009). A Study into the Chinese English Learners' Psychological Process in L2 Discursive Writing. Foreign Language Learning Theory and Practice, (3), 20-27. 
Table 1. College English teachers' age, degrees, and professional posts

\begin{tabular}{|l|l|l|}
\hline Item & Choice & Percentage \\
\hline $\begin{array}{l}\text { 1. How old are } \\
\text { you? }\end{array}$ & $\begin{array}{l}\text { A.25 or less than 25 years } \\
\text { old }\end{array}$ & $32.7 \%$ \\
\cline { 2 - 3 } & B. 26-35 years old & $36.7 \%$ \\
\cline { 2 - 3 } & C. 35-45 years old & $24.5 \%$ \\
\cline { 2 - 3 } & D. More than 45 years old & $6.1 \%$ \\
\hline $\begin{array}{l}\text { 2. What is your } \\
\text { highest degree? }\end{array}$ & A. Associate degree & 0 \\
\cline { 2 - 3 } & B. Bachelor's Degree & $77.6 \%$ \\
\cline { 2 - 3 } & C. Master's Degree & $22.4 \%$ \\
\cline { 2 - 3 } & D. Doctor's Degree & 0 \\
\hline \multirow{3}{*}{$\begin{array}{l}\text { 3. What is your } \\
\text { professional post? }\end{array}$} & A. Assistant teacher & $42.9 \%$ \\
\cline { 2 - 3 } & B. Lecturer & $42.9 \%$ \\
\cline { 2 - 3 } & C. Associate professor & $14.2 \%$ \\
\cline { 2 - 3 } & D. Professor & 0 \\
\hline
\end{tabular}

Table 2. Description of teachers' instruction of college English writing

\begin{tabular}{|c|c|c|c|}
\hline Item & Choice & $\begin{array}{l}\text { Number of } \\
\text { the teachers }\end{array}$ & Percentage \\
\hline \multirow{4}{*}{$\begin{array}{l}\text { 4.How many classes } \\
\text { do you have in a } \\
\text { week? }\end{array}$} & A. $4-6$ periods & 2 & $4.1 \%$ \\
\hline & B. $7-10$ periods & 3 & $6.1 \%$ \\
\hline & C.11-14 periods & 16 & $32.7 \%$ \\
\hline & D. More than 14 periods & 28 & $57.1 \%$ \\
\hline \multirow{4}{*}{$\begin{array}{l}5 . \quad \text { Does your } \\
\text { textbook include the } \\
\text { writing exercises? If } \\
\text { it does, how do you } \\
\text { deal with them? }\end{array}$} & $\begin{array}{l}\text { A. Includes and earnestly } \\
\text { fulfilled }\end{array}$ & 37 & $75.5 \%$ \\
\hline & B. Doesn't include & 0 & 0 \\
\hline & C. Not clear & 2 & $4.1 \%$ \\
\hline & $\begin{array}{l}\text { D. Includes but seldom be } \\
\text { used }\end{array}$ & 10 & $20.4 \%$ \\
\hline \multirow{4}{*}{$\begin{array}{l}6 . \text { How many } \\
\text { periods do you use } \\
\text { for the teaching of } \\
\text { writing for one class } \\
\text { per semester? }\end{array}$} & $\begin{array}{l}\text { A. } 3 \text { periods or less than } 3 \\
\text { periods }\end{array}$ & 19 & $38.8 \%$ \\
\hline & B. $4-7$ periods & 17 & $34.7 \%$ \\
\hline & C. $8-11$ periods & 10 & $20.4 \%$ \\
\hline & D. More than 11 periods & 3 & $6.1 \%$ \\
\hline \multirow{4}{*}{$\begin{array}{l}\text { 7. How many } \\
\text { passages do you } \\
\text { assign the students } \\
\text { every term? }\end{array}$} & A. 3 or less than 3 passages & 9 & $18.4 \%$ \\
\hline & B.4-6 passages & 27 & $55.1 \%$ \\
\hline & C. 7-9 passages & 11 & $22.4 \%$ \\
\hline & $\begin{array}{l}\text { D. } 10 \text { or more than } 10 \\
\text { passages }\end{array}$ & 2 & $4.1 \%$ \\
\hline
\end{tabular}


Table 3. Teachers' Opinions on the Students' Writing

\begin{tabular}{|c|c|c|c|}
\hline Item & Choice & $\begin{array}{l}\text { Number of } \\
\text { the teachers }\end{array}$ & Percentage \\
\hline \multirow[t]{4}{*}{$\begin{array}{l}\text { 8. Do the students } \\
\text { like English writing? }\end{array}$} & $\begin{array}{l}\text { A. Yes, they enjoy it very } \\
\text { much. }\end{array}$ & 0 & 0 \\
\hline & B. Yes, they do. & 20 & $40.1 \%$ \\
\hline & C. No, they don't like it. & 27 & $55.8 \%$ \\
\hline & D. No, they hate it. & 2 & $4.1 \%$ \\
\hline \multirow{4}{*}{$\begin{array}{l}\text { 9. What is the most } \\
\text { difficult factor that } \\
\text { hinders students' } \\
\text { writing? }\end{array}$} & A. Vocabulary & 19 & $38.8 \%$ \\
\hline & B. Grammar & 11 & $22.5 \%$ \\
\hline & $\begin{array}{l}\text { C. Cultural differences } \\
\text { between Chinese and English. }\end{array}$ & 6 & $12.2 \%$ \\
\hline & $\begin{array}{l}\text { D. Writing skills and } \\
\text { techniques }\end{array}$ & 13 & $26.5 \%$ \\
\hline \multirow{4}{*}{$\begin{array}{l}\text { 10. What is the most } \\
\text { serious problem in } \\
\text { the teaching of } \\
\text { college English } \\
\text { writing? }\end{array}$} & A. Lack suitable materials. & 4 & $8.2 \%$ \\
\hline & $\begin{array}{l}\text { B. Improper teaching } \\
\text { techniques }\end{array}$ & 11 & $22.4 \%$ \\
\hline & $\begin{array}{l}\text { C. Students have no interest in } \\
\text { writing. }\end{array}$ & 13 & $26.5 \%$ \\
\hline & $\begin{array}{l}\text { D. CET4(College English Test } \\
\text { Band 4) negative influence on } \\
\text { teaching }\end{array}$ & 21 & $42.9 \%$ \\
\hline \multirow{4}{*}{$\begin{array}{l}\text { 11. Do you think } \\
\text { that CET4 is helpful } \\
\text { for the students to } \\
\text { improve their } \\
\text { writing competence? }\end{array}$} & A. Very Helpful & 0 & 0 \\
\hline & B. Helpful & 24 & $49 \%$ \\
\hline & $\begin{array}{l}\text { C. A little helpful but it also } \\
\text { has negative influence }\end{array}$ & 17 & $34.7 \%$ \\
\hline & D. Unhelpful & 8 & $16.3 \%$ \\
\hline
\end{tabular}

Table 4. Students' views on the teaching of college English writing

\begin{tabular}{|c|c|c|c|}
\hline Item & Choice & $\begin{array}{l}\text { Number of } \\
\text { the students }\end{array}$ & Percentage \\
\hline \multirow{4}{*}{$\begin{array}{l}\text { 1. Are you satisfied with } \\
\text { the teaching of college } \\
\text { English writing? }\end{array}$} & A. Very satisfied & 0 & 0 \\
\hline & B. Satisfied & 37 & $24.5 \%$ \\
\hline & C. Not very satisfied & 64 & $42.4 \%$ \\
\hline & D. Not satisfied & 50 & $33.1 \%$ \\
\hline \multirow{4}{*}{$\begin{array}{l}\text { 2. Is CET4 (College } \\
\text { English Test Band 4) } \\
\text { helpful for you to improve } \\
\text { your writing competence? }\end{array}$} & A. Very Helpful & 4 & $2.7 \%$ \\
\hline & B. Helpful & 57 & $37.7 \%$ \\
\hline & C. A little Helpful & 60 & $39.7 \%$ \\
\hline & D. Unhelpful & 30 & $19.9 \%$ \\
\hline \multirow{4}{*}{$\begin{array}{l}\text { 3. Do you think that your } \\
\text { university attaches great } \\
\text { importance to the teaching } \\
\text { of college English writing? }\end{array}$} & A. Yes, they do. & 1 & $0.7 \%$ \\
\hline & $\begin{array}{l}\text { B. Yes, but just } \\
\text { sometimes. }\end{array}$ & 40 & $26.5 \%$ \\
\hline & C. Not much. & 80 & $53 \%$ \\
\hline & D. No, they don't. & 30 & $19.8 \%$ \\
\hline
\end{tabular}


Table 5. Students' Attitudes toward English Writing

\begin{tabular}{|c|c|c|c|}
\hline Item & Choice & $\begin{array}{l}\text { Number of } \\
\text { the students }\end{array}$ & Percentage \\
\hline \multirow[t]{4}{*}{$\begin{array}{l}\text { 4. What is your purpose } \\
\text { of improving your } \\
\text { writing competence? }\end{array}$} & $\begin{array}{llcc}\text { A. } & \text { To have } & \text { a } & \text { good } \\
\text { preparation } & \text { for } & \text { study } \\
\text { abroad. } & & \\
\end{array}$ & 4 & $2.6 \%$ \\
\hline & $\begin{array}{l}\text { C. For communication and } \\
\text { enjoyment. }\end{array}$ & 47 & $31.1 \%$ \\
\hline & B. To pass the examination. & 53 & $39.1 \%$ \\
\hline & D. To get a better job. & 41 & $27.2 \%$ \\
\hline \multirow{4}{*}{$\begin{array}{l}\text { 5. How much do you like } \\
\text { English writing? }\end{array}$} & A. Enjoy & 7 & $4.6 \%$ \\
\hline & B. It is ok. & 63 & $41.7 \%$ \\
\hline & C. Dislike & 62 & $41.1 \%$ \\
\hline & D. Hate & 19 & $12.6 \%$ \\
\hline \multirow{4}{*}{$\begin{array}{l}\text { 6. How many passages } \\
\text { do you write except the } \\
\text { tasks assigned by the } \\
\text { teacher in one term? }\end{array}$} & A. None & 68 & $45.1 \%$ \\
\hline & B.1-2 passages & 47 & $31.1 \%$ \\
\hline & C.3-5 passages & 18 & $11.9 \%$ \\
\hline & D. More than 5 passages & 18 & $11.9 \%$ \\
\hline \multirow{4}{*}{$\begin{array}{l}\text { 7. Do you usually } \\
\text { translate Chinese into } \\
\text { English while writing in } \\
\text { English? }\end{array}$} & A. Often & 55 & $36.4 \%$ \\
\hline & B. Sometimes & 57 & $37.8 \%$ \\
\hline & C. Seldom & 29 & $19.2 \%$ \\
\hline & D. Never & 10 & $6.6 \%$ \\
\hline \multirow{4}{*}{$\begin{array}{l}\text { 8. What is the most } \\
\text { needed skill that you } \\
\text { want to improve? }\end{array}$} & A. Listening & 14 & $9.3 \%$ \\
\hline & B. Oral English & 114 & $75.5 \%$ \\
\hline & C. Reading & 19 & $12.6 \%$ \\
\hline & D. Writing & 4 & $2.6 \%$ \\
\hline
\end{tabular}

Table 6. Students' difficulties in English writing

\begin{tabular}{|l|l|c|l|}
\hline \multicolumn{1}{|c|}{ Item } & \multicolumn{1}{|c|}{ Choice } & $\begin{array}{l}\text { Number of } \\
\text { the students }\end{array}$ & Percentage \\
\hline $\begin{array}{l}\text { 9. What is the most } \\
\text { difficult factor that } \\
\text { hinders your English } \\
\text { writing? }\end{array}$ & A. Grammar & 18 & $11.9 \%$ \\
\cline { 2 - 4 } & $\begin{array}{l}\text { B. Vocabulary } \\
\text { between Chinese and English. }\end{array}$ & 84 & $55.6 \%$ \\
\cline { 2 - 4 } & D. Writing technique & 24 & $16.6 \%$ \\
\hline $\begin{array}{l}\text { 10. What is the most } \\
\text { serious problem in the } \\
\text { teaching of college }\end{array}$ & A. Lack of teaching materials & 14 & $15.9 \%$ \\
\cline { 2 - 4 } \begin{tabular}{l} 
English writing in your \\
opinion? Improper teaching \\
\cline { 2 - 4 }
\end{tabular} & B. & 23 & $9.3 \%$ \\
\cline { 2 - 4 } & $\begin{array}{l}\text { C. Lack of interest Negative influence of } \\
\text { CET4 }\end{array}$ & 52 & $15.2 \%$ \\
\hline $\begin{array}{l}\text { 11. Do you agree that the } \\
\text { teaching of college } \\
\text { English writings should } \\
\text { be strengthened? }\end{array}$ & A. Strongly agree & 44 & $31.1 \%$ \\
\cline { 2 - 4 } & B. Agree & 83 & $29.1 \%$ \\
\cline { 2 - 4 } & C. Partly agree & 19 & $12.6 \%$ \\
\cline { 2 - 4 } & D. Not agree & 5 & $3.3 \%$ \\
\hline
\end{tabular}

